\title{
JUDICIAL PROFESSION AND OCCUPATIONAL STRESS: A SYSTEMATIC REVIEW APPROACH
}

KEY WORDS: Occupational stress; Work-life balance; Jurisdiction professionals

\section{Dr. Chand P Saini}

\section{Ms.Nisha Gaur}

Associate Professor, Faculty of Commerce \& Management, SGT University, Gurugram, India

\section{Research Scholar, Faculty of Commerce \& Management, SGT University,} Gurugram, India

F This review investigation highlights the occupational stress problem among jurisdiction professionals. Further, this research makes an effort to study the issues generated in jurisdiction professionals' work-life balance due to occupational stress. Family responsibilities \& gathering avoidance, personal discomfort, health issues, and behavioural issues were identified. Implications of this research and future research areas were also discussed.

\section{INTRODUCTION}

Work is a necessary aspect of life, and today's work is marked by unpredictability and long hours. People don't have enough time to deal with their own problems. Also, man has too many responsibilities to fulfill: personal, familial, societal, and professional responsibilities, to name a few. It is necessary to ensure that each responsibility is carried out properly. However, there are occasions when people are unable to carry out their tasks, and this incapacity causes stress. People in positions of professional responsibility must work to fulfil their professional commitments in order to survive, care for their families, and meet personal and societal demands. As a result, professional/work life is a crucial stage in everyone's life.

Professional life is characterized by a number of factors, two of which are particularly essential in the context of occupational stress: organizational demand and employees' competence to perform/deliver the service or goods. When an employee believes that the demands of the stressors (organization) significantly outweigh his or her ability to respond, stress develops(Aswathappa, 2008). Beer and Nawman (1978) defined occupational stress as "A condition arising from the Interaction of people and their jobs and characteristics by changes within people that force them to denote from their normal functioning." Workplace stressors include the nature of the job load, work culture, peer group, work circumstances, given duties and responsibilities, and bosses' attitude toward an employee. Occupational stress is the result of a mismatch between an employee's perception and their capacity to execute. As a result, occupational stress is defined as the combination of the nature of work conditions with the qualities of the worker such that job demands surpass the worker's ability to cope with them (Brabban and Turkington, 2002).

Work stress is not industry specific. It occurs in every profession only the degree can vary (Brabban and Turkington, 2002). Judiciary is also not untouched from the occupational stress. Judiciary possesses a unique status in society because of high power, positions and responsibilities. Decisions taken by judiciary officers greatly impact the thinking of the society. In democratic country like India where there are lots of political and social problems, judiciary role become prominent to maintain law and order in the country. When government failed to protect citizens rights, at that time judiciary proved its supreme position by issuing direction to government for fulfilling their responsibilities.

Occupational stress among jurisdiction professionals always remains ignored issue in previous jurisdiction researches. So, the researcher tried to collect previous scarce review on jurisdiction professionals' stress for identifying causes and impact of work stress.

\section{Review of literature}

There is a scarcity of literature related to stress among jurisdiction professional. The researcher followed a systematic review approach to study occupational stress among judicial professionals. Researches on judicial professionals' occupational stress are discussed here with their key findings:

\begin{tabular}{|c|c|c|}
\hline $\begin{array}{l}\text { Author } \\
\text { name }\end{array}$ & Sample & Findings \\
\hline $\begin{array}{l}\text { Ryan et al. } \\
(1980)\end{array}$ & $\begin{array}{l}3,032 \text { trial judges, } \\
\text { District of Columbia }\end{array}$ & $\begin{array}{l}\text { The study found that Court room structure; Characteristics of attorneys; Availability of } \\
\text { human resource in the court room; Court room personnel }\end{array}$ \\
\hline & & $\begin{array}{l}\text { support; Individual characteristics of judges; } \\
\text { Judges perception towards work impacts the judges' performance. }\end{array}$ \\
\hline $\begin{array}{l}\text { Rogers et al. } \\
(1991)\end{array}$ & $\begin{array}{l}104 \text { judges and } 48 \\
\text { spouses of judges }\end{array}$ & $\begin{array}{l}\text { Study highlighted that judges perceived work itself (e.g. sentencing, child custody, } \\
\text { judgment, jury trials) major source of stress. } \\
\text { This study further explored that work nature as a major cause of stress as compared of } \\
\text { job factors like employer employee relations, role conflicts and career development }\end{array}$ \\
\hline $\begin{array}{l}\text { Anleu and } \\
\text { Mack (2005) }\end{array}$ & 40 magistrates & $\begin{array}{l}\text { Study focused on the importance of emotional labour. The study found that magistrates and } \\
\text { some of the legal representatives presented in the courtroom manage their emotions like } \\
\text { anger, distress against the social problems that may need emotional response. }\end{array}$ \\
\hline $\begin{array}{l}\text { James, C. } \\
(2006)\end{array}$ & Sample of lawyers & $\begin{array}{l}\text { This study considered working conditions as a major cause of work stress rather than } \\
\text { nature of legal work itself. Management issues, long hours of work, absence or poor } \\
\text { quality mentoring and supervision in the initial years of practice were also found the } \\
\text { cause of work stress among lawyers. }\end{array}$ \\
\hline $\begin{array}{l}\text { Lustig et al. } \\
(2008)\end{array}$ & \begin{tabular}{|l|}
212 immigrated \\
judges United States
\end{tabular} & $\begin{array}{l}\text { The study used Secondary Traumatic Stress Scale (STSC) and the Copenhagen Burnout } \\
\text { Inventory (CBI) and found that sampled population was } \\
\text { suffering from the secondary traumatic stress. }\end{array}$ \\
\hline $\begin{array}{l}\text { Flores et al. } \\
(2009)\end{array}$ & $\begin{array}{l}163 \text { American trial } \\
\text { judges }\end{array}$ & $\begin{array}{l}\text { Judges facing general stress and trial stress. They also reported highest level of stress } \\
\text { during verdict of crimes against children, sexual crimes and violent crimes. }\end{array}$ \\
\hline
\end{tabular}




\begin{tabular}{|c|c|c|c|}
\hline \multicolumn{2}{|c|}{\begin{tabular}{|l|l|} 
Tsai and Chan 180 lawyers from 26 \\
\end{tabular}} & \multicolumn{2}{|c|}{ Stress among lawyers associated } \\
\hline$(2009)$ & & \multicolumn{2}{|c|}{$\begin{array}{l}\text { personal and work related burnout. Lawyers } \\
\text { perceived higher stress on the basis of job control, psychological demands and efforts }\end{array}$} \\
\hline & & \multicolumn{2}{|c|}{$\begin{array}{l}\text { This study highlighted stress on the basis of Job control, Psychological demand Effort, } \\
\text { Reward, Over commitment. Also, research found that judicial officers facing personal } \\
\text { work related and client-related burnout problems. }\end{array}$} \\
\hline & & \multicolumn{2}{|c|}{$\begin{array}{l}\text { Emotional exhaustion, stress due to clients, work under load and economic position is } \\
\text { the major cause of job dissatisfaction among lawyers. }\end{array}$} \\
\hline$(2012)$ & & \multicolumn{2}{|c|}{$\begin{array}{l}\text { The study found that } 88.3 \% \text { sampled lawyers had experienced stress. Female lawyers } \\
\text { experienced more stress and burnout as compared of male lawyers. Job satisfaction } \\
\text { found significantly and negatively related with stress. }\end{array}$} \\
\hline$(401$ & & \multicolumn{2}{|c|}{$\begin{array}{l}\text { Results of the study highlighted that emotional exhaustion, conflicts between values and } \\
\text { practices, strained interpersonal relationship, over expectations, jealously, poor economic } \\
\text { position, competition, conflicts between values and practices, reduced personal } \\
\text { accomplishment, stress, depersonalization, poor social position, non- availability of } \\
\text { resources, work overload, work under load causes stress among judicial personnel. }\end{array}$} \\
\hline & lawy & \multicolumn{2}{|c|}{$\begin{array}{l}\text { This study found that home and work imbalance, managerial roles, insufficient } \\
\text { recognition, managerial roles and hassles were the major cause of stress among lawyers } \\
\text { and legal professionals. }\end{array}$} \\
\hline & & & \\
\hline mans & $\begin{array}{l}452 \\
\text { lawy }\end{array}$ & \\
\hline \multicolumn{4}{|c|}{ 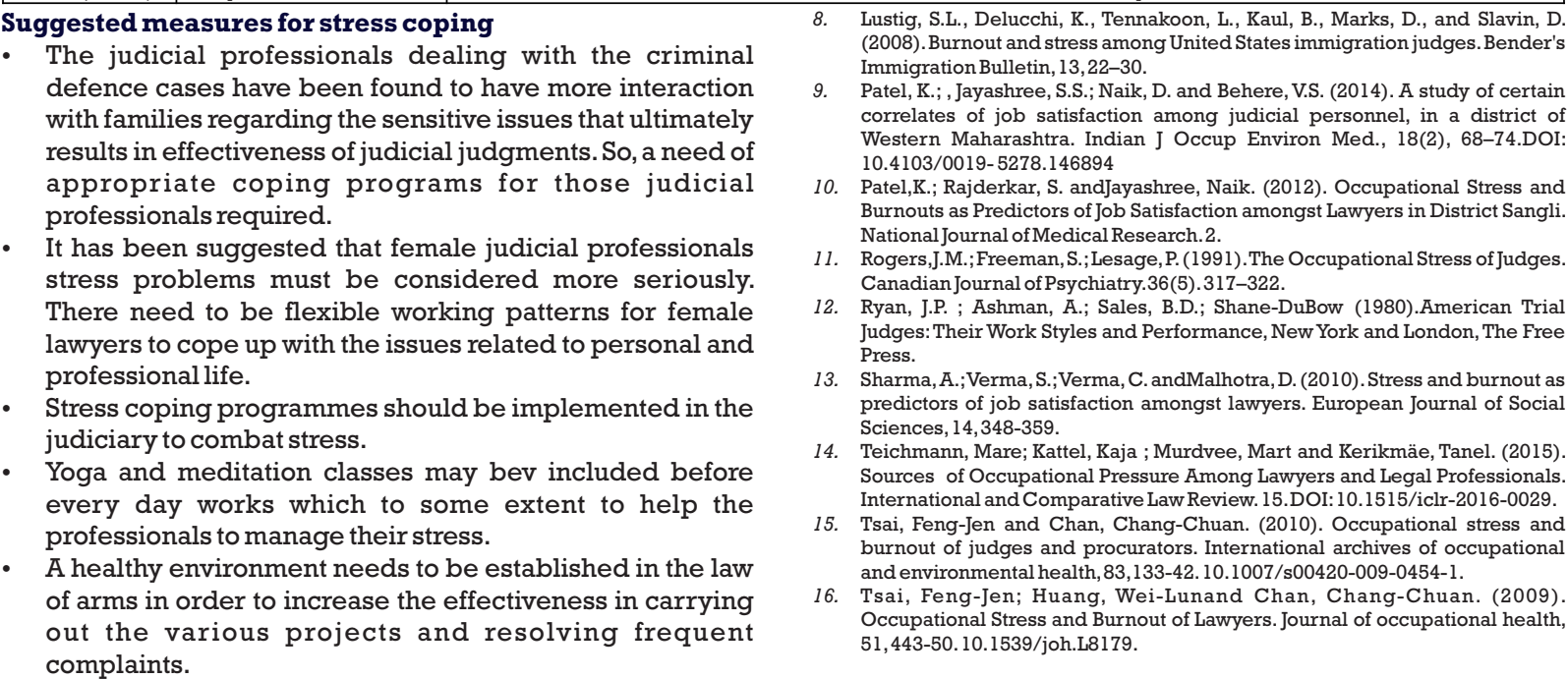 } \\
\hline
\end{tabular}

\section{CONCLUSION:}

There is extensive literature available related to work stress and its impact on work-life balance, but literature is scarce in the context of jurisdictional professionals. So this study is an attempt to strengthen the literature base related to workrelated stress and the work-life balance of jurisdiction professionals. Also, through this investigation, potential stressors among jurisdiction professionals were identified that guide the authorities to take corrective actions in this direction. So, there will be harmony between jurisdiction members personal and professional life.

\section{REFERENCES}

1. Alaguthankamani, M. (2017). A study of job stress among advocates practicing in Chennai city,Thesis submitted in University of Madras.

2. Anleu, S.R. and Mack, K. (2005). Magistrates' Everyday Work and Emotional Labour. Journal of Law and Society, 32(4), 590-614.

3. Aswathappa, K. (2008). Human resource management: Text and cases. Delhi Tata McGraw-Hill Publishing.

4. Beeha and Newman (1986), "The current debate about the meaning of job stress." Journal of Organisation Behaviour Management.

5. Brabban, A. andTurkington, D. (2002). The Search for Meaning: detecting congruence between life events, underlying schema and psychotic symptoms. In A.P. Morrison (Ed).A Casebook of Cognitive Therapy for Psychosis (Chap 5,p59-75). NewYork: Brunner-Routledge.

6. Flores, D. M., Miller, M. K., Chamberlain, J., Richardson, J. T., \& Bornstein, B. H. (2009). Judges' perspectives on stress and safety in the courtroom: An exploratory study. Court Review, Volume 45, Issue 3,76-89

7. James, Colin. (2008). Lawyer Dissatisfaction, Emotional Intelligence and Clinical Legal Education. Legal Education Review, 18, 123. 